\title{
Ecological preservation versus economic exploitation of natural resources: a happy marriage or a bitter divorce?
}

\author{
Nuno Eduardo M. M. E. Formigo \\ Departamento de Zoologia-Antropologia, Faculdade de Ciências da Universidade do Porto. Praça Gomes \\ Teixeira. 4099-002 Porto. Portugal
}

\begin{abstract}
The purpose of this work is to integrate two important areas: the water uses and their ecological impacts; the economical and legal issues related to the sustainable exploitation of the natural resources. Another purpose is to relate these two areas and the local and regional interests in the conservation of these resources. Some case studies are presented in which a balance between the two issues was attempted: a small watershed in the North of Portugal, and the minimisation of the impact of a dam on the fish populations. In both cases the regional economy is considered.
\end{abstract}

Keywords: wetlands, hydrology, wetland restoration

\section{RESUMEN}

El presente trabajo intenta integrar dos areas distintas: los diferentes usos del agua y sus consequencias ecologicas; las questiones economicas y legales relacionadas con el problema de la explotacion sustenible de los recursos naturales. Se intenta, de igual modo, hacer la relacion entre estas dos areas y el interes local y regional de la preservacion de esses mismos recursos. En primer lugar se referiran, sucintamente, algunos de los diferentes usos del agua y sus consequencias.Despues, se referiran, sucintamente, algunas de las principales questiones legales y economicas relacionadas con la explotacion sustenible de los recursos naturales. Finalmente, se presentaran dos casos de estudio, en los quales se ha intentado lograr el equilibrio entre las dos areas: la gestion de una pequena cuenca del norte de Portugal y la minimizacion del impacte de un embalse sobre las poblaciones de peces. En ambos casos se intenta tambien hacer la relacion con la economia de las regiones donde se inseren los proyectos.

Palabras clave: humedales, hidrología, restauración de humedales

\section{INTRODUCTION}

The present work proposes to discuss, in a concise way, some of the alternatives that, at the present time, can be used to promote the valuation of natural resources in general, and of water courses in particular. For a long time, the preservation of natural resources and the environment was presented as being incompatible with economic development. With the expansion and degradation of urban areas, natural values and resources became more and more restricted to the non-urban areas (mainly, those away from the coastal zone), precisely the ones where economic underdevelopment has been greater. This fact has increased the difficulties of dealing with a dilemma that was regarded, for a long time, as unsolvable. On the one hand, the growing lack of natural resources, ecologically balanced and not disturbed by man, has increased the corresponding heritage value and 
need for preservation. On the other hand, the declining profits of agricultural activities and human emigration for urban areas contributed to the desertification of the non-urban areas, thus deepening their economic underdevelopment.

The ideal solution for this dilemma has to include, necessarily, alternative ways of exploiting the natural resources and the environment, that could transform them in generators of added value, both at the local and regional scales.

The possibility of implementing this type of solution has emerged with a change in the cultural habits of the society, during recent years. Partially due to the intense pressure of the ecologist movement, the preservation and rational management of natural resources has begun to acquire an increasing importance and acceptance in wider and wider sectors of public opinion.

Environmental issues have become a part of the political agenda. As a consequence, in a gradual way, a growing amount of public funding has been invested in this sector (Peyton, 1987). At the same time, this increasing importance, in terms of public opinion, of the environment and natural resources, has brought them to the attention of many economic agents (Cohen, 1978; Inskeep, 1987; Mery, 1992).

\section{THE EXPLOTATION OF FRESHWATER RESOURCES}

Fresh water is only $2.7 \%$ of the total amount of water available on the planet. Of this, only $22.8 \%$ is in a liquid state. Nevertheless, freshwater resources are fundamental for the survival of the different types of life forms existing on Earth. The amount of water available at each moment depends on the functioning of the water cycle. In fact, it is the existence of such a cycle that makes water a renewable resource.

Man is the main disturbing agent of the proper operation of this cycle. Among the many uses of fresh water are domestic and industrial supply, agricultural irrigation, electricity production and recreational activities. Although it is true of some more than others, all these human uses of fresh water have consequences on the water cycle and on the environment.

Dam construction changes the dynamics of sediment transportation in fluvial systems, prevents the upstream migration of many animal species, etc.

When the water used for agricultural purposes returns to the watercourses, it brings a significant amount of nutrients and organic matter, which will cause a decrease in quality. Another consequence of irrigation is the erosion of the land, increasing the amount of suspended solids in the receiving watercourses.

Domestic and industrial sewages that return to watercourses contain, normally, several pollutant substances. In the case of domestic sewage, these are mainly composed of organic matter. In the case of industrial sewage, they can be of several different types.

Recreational uses of water include angling, boating and swimming. In all these situations, one of the main impacts is caused by the excessive number of people that concentrate close to the watercourse, damaging mainly its banks, whose preservation is particularly important because of the role they play as ecotones. In the case of angling, there is an additional impact due to a possible over-exploitation of the resource, especially in the case where there is no stocking. When stocking is done, another impact is related to the use of non-authoctonous species and to eventual disturbances caused in the community structure (Cox, 1991; Azevedo \& Formigo, 1996)

Finally, in terms of the proper functioning of the water cycle, the main consequence of the human uses of fresh water is the degradation of its quality, which has two important consequences: it shortens the global availability of good quality water and it creates an increasing need to use artificial processes of water purification, which are much more expensive.

\section{AN ECONOMIC APPROACH TO FRESH- WATER RESOURCES}

The problem of the human uses of freshwater resources is now approached, not in ecological 
terms, but in economic terms. Three main difficulties arise: the property of the resource; the protection against negative externalities; the definition of sustainable forms of exploiting renewable resources.

\section{PROPERTY RIGHTS}

Property is a legal mechanism which ensures the right of use, although it may be subjected to several possible types of restrictions. It is an essential condition in economic exchange: no one would pay for a given good without the certainty of being able to use it, or without the guarantee of being able to prevent others from using it without payment.

Thus, property rights define the proper relations between people, concerning the use of things, and the corresponding penalties for the violation of those proper relations.

Nevertheless, there is a certain number of goods (such as many environmental goods), services, commodities and resources (such as some natural resources) that are non exclusive. Non exclusiveness is an attenuation of property rights. Without exclusiveness of use it is impossible to charge a price for the right of use.

The typical result of non exclusiveness is insufficient supply of those goods and services, overexploitation of the resources and under-investment in their management and preservation.

The solution for such a problem seems obvious: to restore the exclusiveness of use. There are two main reasons why, despite of this apparently simple solution, some cases of non exclusiveness still exist. The first one concerns cultural and political reasons: every society considers that there is a certain number of goods and services that must not be submitted to market laws. It is the case with certain places of historical interest, certain places with a high environmental value, etc. The second one concerns the fact that many resources, due to their physical characteristics, prevent the specification of property rights. It is the case with air, underground water, rivers, the sea, schools of fish, etc.
Rules that define who will have access to the resource, and under what conditions, may be defined and implemented. For example, as is the case with hunting and angling, these rules may include the payment of a licence, the limitation of the maximum number of licenses to be issued, the definition of the maximum amount of exploitable resource, the definition of time periods for the exploitation, the limitation of the exploitation methods that can be used, etc.

Some authors use the concept of public goods to designate the set of goods which are non exclusive. (Randall, 1987; Common, 1988; Pearce \& Turner, 1990; Bromley, 1995; Faucheux \& Noel, 1995)

\section{EXTERNALITIES}

An externality is said to exist whenever the activities, or the welfare, of an individual are affected, not only by his or her own activities, but also by the effect of one or more activities that are not under his or her control. An externality is said to be negative if the affected part is seeking to reduce the activity of the part that is causing it. The simplest solution for the externalities problem is the definition of a price corresponding to its value. Thus, the part that is causing it is motivated to reduce it until an efficient costs structure is reached, and the part that's suffering it is incentivated to tolerate it, due to the additional profit it brings. The solution proposed above is known as the Coase theorem. Nevertheless, it does not allow the elimination of externalities associated with non exclusiveness (Randall, 1987; Common, 1988; Pearce \& Turner, 1990; Bromley, 1995; Faucheux \& Noel, 1995).

\section{SUSTANABLE EXPLOITATION OF RENEVABLE NATURAL RESOURCES}

The main characteristic of a renewable resource is that its amount is variable in time. It will increase if the resource is allowed to recover, although there is an upper limit: no resource can 
grow behind the point corresponding to the carrying capacity of the system on which it exists (for example, water in a reservoir, fishes in rivers, trees in forests, etc.). A renewable resource can also be exhausted and become non-renewable.

Another essential characteristic of living resources is their dynamic state of equilibrium, which is regulated by biological processes. A second type of dynamics, of an economic type, will then overlay the biological one, being responsible for regulating exploitation of the resource.

From the standpoint of the biological balance of the resource, the amount of maximum exploitation must coincide with the capacity of the resource to recover, what is normally known as maximum sustainable yield. In practice, and because of the biological dynamics of the system, it is wise to adopt limits of exploitation that allow the inclusion of a safety interval.

The exploitation of the resource behind this biological equilibrium limit leads to a situation of over-exploitation and the resource is no longer able to recover. From the economic standing point, the ideal level of exploitation of the resource is the one corresponding to the maximum profit. In the long term, this coincides with a biologically equilibrated exploitation. Nevertheless, in the short term, it is beyond that level, leading to over-exploitation. Thus, a conflict arises between the biological and the economic perspectives.

There are several possible solutions to this conflict, largely dependent on the type of property rights that can be specified on the resource. If it is possible to define a set of property rights based on private property, the tendency of the proprietor will be to maximise the long-term profit. This solves, in a satisfactory way, the above mentioned conflict. It is the case with a forest, an aquaculture facility, etc.

If it is impossible to define a set of property rights on the resource, the tendency will be to over-exploitation of the resource in the short term, due to the additional profit thus generated.

One of the possible solutions consists in the definition of a maximum limit for the level of exploitation. Up to that limit, the access to the resource can be defined either through free market laws, or through the definition of individual quotas, that can then be traded between those interested on them. Finally, another type of solution, is a system of progressive taxes on the profits gained with the exploitation of the resource, shifting the costs curve in such a way that, in the short run, the economic limit for exploitation coincides with the biological one (Randall, 1987; Common, 1988; Pearce \& Turner, 1990; Bromley, 1995; Faucheux \& Noel, 1995).

\section{ECONOMY VERSUS ECOLOGY: WHAT CAN BE DONE?}

This work is based on a strong belief: it is possible, if not unavoidable, to bring together the preservation and the economic exploitation of freshwater resources, to promote the economic and social development of the populations that live within their areas of influence.

The concept of protected area implies that, if it exists, there was a need to protect it from the degradation of the territory surrounding it. Thus, more important than the need to create protected areas, is the achievement of a situation in which there is no need to create them.

In the following paragraphs some concrete ways of bringing together preservation and economic exploitation are suggested.

- Every activity of environmental preservation, from which an excessive isolation of the area is the outcome, creates a negative image in public opinion, being against the goals of a proper environmental education of the public.

- Every activity of environmental preservation must be done together with the local populations and, preferably, for them. This means that it must not be the cause of any loss in their life quality, and that it should, as far as possible, bring together the preservation of the environment and their expectations concerning an increase in their life standards.

- Enjoying a preserved environment must be considered as a service that has a given cost; 
part of it should be viewed as a social cost, to be paid by the government; nevertheless, if emigration is to be avoided and the maintenance of local populations promoted, the economic exploitation of natural resources must be encouraged, as far as it is compatible with its preservation in the long run.

- Concerning the legal framework presently existing in Portugal, a comprehensive transformation is required, in order to allow new ways of defining property rights in terms of natural resources and the environment, as well as a clear statement on the rights and duties that are included in these property statements.

Next, examples of the application of these principles to two real cases will follow.

\section{THE RIVER ANCORA AS A GENERATOR ADDED VALUE AT THE LOCAL AND REGIONAL LEVEL}

The river Ancora valley has a high diversity of natural values, such as weirs, waterfalls, beautiful landscapes, and a proper balance between agriculture, forest and the river. Because of its high degree of preservation, they have a valuable potential for touristic development (Formigo et al., 1993; Formigo, 1997).

The human heritage is also valuable. Watermills still in use, traditional forms of agriculture, historical and religious monuments, are just some of these.

Finally, the area has good access by road, and there are several kinds of tourism support services, like hotels and restaurants.

Thus, it is only natural that the local authorities and groups of citizens try to have the area declared as protected landscape. It is also not surprising that some tourism firms promote rafting on the river and visits to some remote sites of a high environmental value.

On the basis of all the previous considerations, the following proposals are ways of bringing together environmental preservation and economic exploitation of the natural resources of the Ancora river valley.
- Rural tourism - recovery of some of the traditional houses and their exploitation for tourism.

- Environmental education campaigns, directed at the local populations, in order to make them realise the natural value of the valley and to promote the prevention of summer forest fires.

- Definition of an integrated policy of urban development for the whole valley, in order to control both the number and type of houses being built.

- Use of the valley as an environmental study area for schools (both local and regional) and for the practice of controlled leisure time activities.

- A rational management of the tourist flows during the year, in order to avoid seasonal imbalances, namely in the summer.

- The definition of several ways of exploiting the river, namely:

- the controlled exploitation of the existing angling concession, which has been inactivate for many years now (Formigo et al., 1994; Jesus \& Formigo, 1996);

- the definition of trails, both for walking and for horse-riding, along the whole valley, both general and thematic (natural, historic, ethnographic, etc.);

- the proper use of the existing fluvial beaches;

- the controlled possibility of camping.

\section{THE BAIXO SABOR DAM PROJECT: THE VILARIÇA CREEK AND THE MINIMISA- TION OF THE DAM IMPACT ON THE FISH COMMUNITY}

The Baixo Sabor dam project (River Douro drainage basin) consists of the building of two dams (a main one and a flow regulation dam).

Concerning the fish community, the rise in the water level, due to the dam construction, will submerge the current river banks, a privileged shelter area for the existing fish populations. It will also cause the functional disabling of the 
existing gravel beds, essential for fish reproductive behaviour. (Formigo et al., 1998)

Generally speaking, the fish diversity in the River Douro drainage basin is present in the River Sabor and its tributaries. Eight species were found. Nevertheless, trout and all the species of the Rutilus alburnoides and Rutilus arcasii complex were absent. Migratory species (as shad, eel and lamprey) were also not found.

Of all the species found, barbel is the most important one. On two different occasions (May and June 1997), thousands of animals were found in a gravel bed located within the area of the future flow regulation dam, about one mile upstream from the mouth of the Vilariça Creek. The majority of the animals were barbels.

A possible explanation for this fact, although it lacks confirmation, considers the possibility that most of these animals come from the next downstream reservoir. Amongst others, some of the facts that support this hypothesis are as follows. The existence, a few miles upstream from this place, of a hydrometric station, whose wall acts as a barrier against the upstream migration of the animals, leads to the assumption that they are not related to the populations located upstream. Also the fact that there are no significant tributaries, except this river, before the next reservoir downstream, leads to the assumption that this river acts as the only place where this population can spawn. Finally, the number of animals observed was clearly much higher than what could be expected for a local population, given the site characteristics, even considering very optimistic estimates of the carrying capacity.

The only tributary of the Sabor that has its mouth located below these dams is the Vilariça Creek. In March 1997, barbels of a considerable size were found in this watercourse, especially close to its mouth. This may be interpreted as the beginning of the reproductive migration period. Also the presence of smaller animals of the same species upstream in this creek is a good indicator of the success of the reproduction that has taken place here.

Finally, the great number of animals found in the River Sabor, about one mile upstream from the mouth of the Vilariça Creek, means that this creek, under its present conditions, has no capacity to be used as an alternative to the spawning of the animals of this species.

Given all the facts mentioned in the previous paragraphs, the following solution is proposed to achieve the minimisation of the dam impact, from the ecological standpoint, with the minimal possible economic costs to the exploitation of the dam complex. It starts from the following statements:

- the Vilariça creek has the necessary conditions for the spawning of most fish species present in the lower course of River Sabor, as can be deduced from the sampling results;

- the average annual discharge seems, nevertheless, insufficient to allow a significant increase in the number of animals that can spawn there;

- the average annual discharge, particularly during the period of the reproductive migration, will be insufficient to serve as an attractor for the reproducing animals, since the mouth of this creek will be very close to the dam;

- the bed of the Vilariça Creek has the capacity, namely in terms of banks, to allow an increase in the discharge, that would imply no expense in the purchase of marginal lands; Given the statements above, the following measures are proposed:

- the construction of a waterway between the dam and the Vilariça Creek, that allows an increase in the discharge of the creek, in order to achieve the intended effects, in terms of minimising the dam impact;

- the discharge established should be managed, in real time, with the natural discharge of the creek, in order to allow an effective prevention of flood events;

- on its way to the creek, the water may pass through a small hydroelectric power plant, allowing the reduction in the costs of the proposed measure;

- the proposed solution implies a previous viability study and, in case of implementa- 
tion, a process of monitoring that allows for the detection and correction of eventual shifts from the intended objectives.

This solution allows the continuation of a project which has undeniable importance, both in local and national terms. Its existence is an obvious factor for the economic development of the local populations. The energy produced will diminish the country's external dependence on electricity. The construction of the small power plant allows the preservation of the fish populations without an excessive cost in energy and economic terms.

\section{CONCLUSION}

The present work has tried to present a different approach to the problem of preserving freshwater resources. Using both theoretical considerations and real examples, the objective was to demonstrate that it is not always impossible to bring together preservation and economic welfare. When properly balanced, both objectives can make a significant contribution to an increase in the living standards of the local populations, preventing human desertification of the regions where most of the resources that need preservation are located.

\section{REFERENCES}

AZEVEDO, M. \& N. FORMIGO. 1996. A gestão da pesca desportiva em águas interiores: o caso português e alguns exemplos europeus. Actas da $5^{a}$ Conferência Nacional Sobre a Qualidade do Ambiente, Aveiro, Portugal, Volume II: 2035-2044.

BROMLEY, D. 1995. The Handbook of Environmental Economics. Blackwell Publishers, Oxford.

COHEN, E. 1978. The impact of tourism on the physical environment. Annals of Tourism Research, 5(2): 215-237.

COMMON, M. 1988. Environmental and Resource Economics: an Introduction. Longman, London.

COX, W. 1991. The legal framework for river use in the United States. Regulated Rivers: Research \& Management, 6: 101-107.
FAUCHEUX, S. \& J. NOEL. 1995. Economie des Ressources Naturelles et de l'Environnement. Armand Colin, Paris.

FORMIGO, N., M. COELHO, M. CERQUEIRA \& M. J. CUNHA. 1993. Rio Âncora - Caracterização ecológica através do estudo do plâncton, do perifiton e da ictiofauna. Projecto NATO-PO-RIVERS, Actividade de Caracterização Biológica, Relatório Final, 120 pp.

FORMIGO, N., T. JESUS, J. P. PEREIRA, L. SERRA \& G. R. TAVARES. 1994. Algumas características da ictiofauna da bacia hidrográfica do rio Âncora. Actas da $4{ }^{a}$ Conferência Nacional Sobre a Qualidade do Ambiente, Lisboa, Portugal, Volume III: 11-15.

FORMIGO, N. 1997. A bacia hidrográfica do rio Âncora: caracterização ecológica e potencialidades bioeconómicas para a prática da pesca desportiva. Dissertação de doutoramento, Faculdade de Ciências da Universidade do Porto. 500 pp.

FORMIGO, N., P. SANTOS, T. JESUS, C. FIGUEIREDO, F. RIBEIRO \& G. R. TAVARES. 1998. Estudo de impacto ambiental do empreendimento hidroeléctrico do Baixo Sabor - qualidade biológica da água e comunidade piscícola. (mimeo) $87 \mathrm{pp}$.

INSKEEP, E. 1987. Environmental planning for tourism. Annals of Tourism Research, 14: 118-135.

JESUS, T., \& N. FORMIGO, N. 1996. Utilização do habitat pela comunidade piscícola do rio Âncora: implicações ecológicas e consequências para o ordenamento piscícola. Actas da $5^{a}$ Conferência Nacional Sobre a Qualidade do Ambiente, Aveiro, Portugal, Volume II: 1353-1360.

MERY, J. 1992. Tourisme rural et environnement. Espaces, 113: 24-28.

PEARCE, D., \& R.TURNER. 1990. Economics of Natural Resources and the Environment. Harvester Wheatsheaf.

PEYTON, R. 1987. Mechanisms affecting public acceptance of resource management policies and strategies. Can. J. Fish. Aquat. Sci., 44 (Suppl.2): 306-212.

RANDALL, A. 1987. Resource Economics: an Economic Approach to the Natural Resources and Environmental Policy. John Wiley \& Sons, N.Y. 